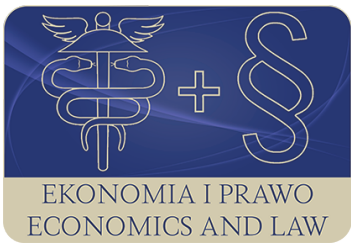

EKONOMIA I PRAWO. ECONOMICS AND LAW

Volume 17, Issue 4, December 2018

p-ISSN 1898-2255, e-ISSN 2392-1625

www.economicsandlaw.pl

ORIGINAL ARTICLE

received 02.01.2018; revised 01.06.2018; accepted 31.12.2018

Citation: Lemkowska, M. (2018). Environmental Liability Directive call for development of financial instruments: the issue of compulsory insurance. Ekonomia i Prawo. Ecomomics and Law, 17(4): 383-403. doi:10.12775/EiP.2018.028.

\title{
Environmental Liability Directive call for development of financial instruments: the issue of compulsory insurance
}

\author{
MALWINA LEMKOWSKA \\ Poznań University of Economics and Business, Faculty of Economics, Department of Insurance, \\ al. Niepodległości 10, 61-875 Poznań, Poland \\ $\square$ malwina.lemkowska@ue.poznan.pl
}

\begin{abstract}
Motivation: Compulsory insurance is one of the possible optional responses to the Environmental Liability Directive (ELD) call for development of financial instruments. The article is a contribution to the analysis of the development of financial instruments relating to environmental liability. The above has been continuously discussed in both local and European circles.

Aim: There are two research purposes of this article. Firstly, to identify the attributes of the EU countries which have implemented a system of obligatory environmental insurance. Secondly, to recognise and assess the premises for introduction of a system of obligatory environmental insurance by the example of Poland.

Results: Insurance obligation has been legitimised in relatively poorly developed countries of the European Union. Economic indicators (GDP, GDP per capita) in majority of the above are usually below the EU average. Also, the attributes of insurance markets

(non-life insurance gross premium written, non-life insurance density and insurance penetration rates) in these countries are the evidence of a large discrepancy between them and the highly developed markets. Overall economic indicators for Poland and the attributes of the Polish insurance market put this country (in economic terms) in the group of states which have decided to introduce obligatory environmental insurance. Simultaneously, the doctrine and practitioners alike consistently criticise 'inflation of obligatoriness' which has been seen in the Polish regulations for decades and indicate disadvantages of such solution. Possible introduction of environmental insurance obligation, if con-
\end{abstract}


sidered in Poland, should be preceded by action taken in order to strengthen the supply side of the market. Only in this condition will it be possible for obligatory insurance - if flexible enough in its structure - to strengthen the incentives for market development on the demand side.

Keywords: environmental insurance; compulsory insurance; Environmental Liability Directive JEL: G22; Q58; K12

\section{Introduction}

The article no. 14 of the EU directive concerning environmental liability with regard to the prevention and remedying of environmental damage (Directive 2004/35/CE, 2004) has been continuously discussed in both local and European circles. The law requires member states to provide conditions for development of financial instruments which will provide the cover for the liabilities connected with prevention and remedying of environmental damage. Law encourages certain behaviours without describing their attributes. It is exactly this open character of the regulation that enables development of an array of creative solutions across the whole of the EU. In large majority, the solutions are based on the private insurance mechanism even though the directive does not suggest a limited catalogue of financial instruments ${ }^{1}$. An overview of the EU activities points at the environmental insurance pools (Spain, France, Italy), drawing up non-binding model policy wordings (Germany, Austria), development of independent, voluntary environmental insurance products (Great Britain), or finally, expanding the products relating to civil liability to encompass environmental liability based on ELD requirements as well (Germany) (Insurance Europe, 2013, p. 16). Along with the aforementioned autonomous initiatives stemming from the insurance sector, some countries undertake regulatory action which requires certain groups of entities to obtain insurance against liabilities resulting from environmental damage. Up till now Poland hasn't taken any special actions to react to the call of ELD. Obligatory insurance is one of the possible optional responses to the directive in Poland. The article is a contribution to the analysis of the development of financial instruments relating to environmental liability.

\section{Literature review}

Global literature on the subject of insurance obligation is relatively scarce. Usually, obligatory insurance is considered with respect to regions, especially regarding obligatoriness of one product line. This stems from countries' autonomy in implementation of obligatory systems, even in such structures like the EU.

${ }^{1}$ In the light of the directive all financial instruments that constitute security for liabilities are acceptable (Bergkamp \& Goldsmith, 2013, p. 127). It is hard to overlook the fact, though, that the European legislation itself favors in article 14 par. 2 of ELD insurance products and suggests them as most recommendable. 
Moreover, contractual obligatoriness does not belong to the realm of market economies and its roots go back to statist economic policy. However, the authors emphasise vast experience in using obligatoriness, including the states which at present are clear about its support for non-obligatory character of the market ${ }^{2}$. It is also indicated that the option of obligatory insurance is seriously considered by both egalitarian and libertarian economists (Bou-Habib, 2006, p. 250). The available analyses focus on either searching for a justification for introduction of obligatoriness in particular product lines (Bou-Habib, 2006, p. 243; Faure, 2006, p. 149; Feng et al., 2014, p. 211) or describing certain legal solutions in particular countries (Dragota et al., 2012, p. 177; Faure, 2001, p. 26; Feng at al., 2014, p. 211; Franc \& Pierre, 2015, p. 1l; Guo, 2016, p. 26; Zhu, 2014, p. 67). The latter analyses aim to identify the strengths and threats which some of the structure attributes may generate.

When researchers deal with the first area of their interest, they identify economic and non-economic motivators to implementation of obligatory insurance. In some cases, economic factors lead to larger effectiveness of the obligatory market (compared to voluntary one) and they vary slightly, depending on the insurance being first party (victims' insurance) or third party (liability insurance). In both cases, the analyses revolve around the lack of sufficient information or occurrence of external effects, and in the area of liability insurance they often refer to the issue of moral hazard. Arguments for obligatory solutions are based on the assumption that only the unrestricted access to the complete information about perils would be the guarantee of economic effectiveness of non-obligatory market. The decision of non-insuring is often the consequence of the poor access to information. The lack of insurance generates in turn external costs of this decision for the society. It is firmly stated, though, that the above arguments will be valid enough to introduce obligatory insurance only if the legislators ensure control of moral hazard, especially in liability insurance (Faure, 2006, p. 149).

Among the non-economic premises for liability systems one should mention social aspects, such as aiming at alleviation of social disparities and eradication of poverty (Dragota et al., 2012, p. 177), providing public health (Franc \& Pierre, 2015 , p. 111), a compensation guarantees for victims in the case of improper action by the entity liable for the compensation (also in the case of the entity's insolvency) (Zhu, 2014, p. 67). Some of the authors even state that the obligation results from the need to protect the authors of the damage against their insolvency (Zhu, 2014, p. 67). The above are qualified as paternalistic motivators for implementation of obligatory insurance (i.e. protection of those who for various reasons are unable to safeguard their interest on their own) as opposed to economic factors which result in a largely non-paternalistic approach (the obligation is not imposed with a view to protection of potential insureds or individual

${ }^{2}$ For example, Great Britain which introduced obligatory automobile insurance as early as in the 1930's, also possesses vast experience in obligatory insurance because of the so called Employers Liability Act imposed in 1969 (Gauci, 2014, p. 77). 
victims. It is used for ensuring an optimized economic balance of the market) (Bou-Habib, 2006, p. 251).

The other research area which, in turn, aims to analyse particular product-related solutions, focuses most often on health, liability insurance or property insurance against natural disasters. It is pointed out that the precondition for effectiveness of obligatory insurance is a well-thought-out structure in terms of its subject and object-matter scope. The researchers have realised that against the declared functions, the system can sometimes exacerbate disparities (e.g. badly designed premium subsidy system (Franc \& Pierre, 2015, p. 11l) or solve the problem of poverty through removal of non-essential factors ${ }^{3}$ (Dragota et al., 2012, p. 185), discriminate against some social groups (e.g. obligatory health insurance only for those with a permanent employment contract (Franc \& Pierre, 2015, p. 111) or it may improve the victims' situation only to a limited extent (liability insurance based on 'pay to be paid' rule) (Zhu, 2014, p. 72).

The literature is remarkably enhanced by the compilations on obligatory environmental insurance. The ELD triggered a discussion on introduction of obligatory insurance on the European scale. The main participants of the debate are the European Commission (2010, p. 8; 2016b, p. 7), the association of European insurers - Insurance Europe (2013, p. 14; 2015, p. 36) and the representatives of the demand side of insurance market (Ad-hoc Industry Natural Resource Management Group, 2009, pp. 9-11). All the parties have come to an agreement that at the EU level obligatory insurance is not a good solution. What is more, a series of arguments was presented which undermine the idea of obligatoriness on the insurance market per se, regardless of its territorial scope. Consequently, the obligation to sign an environmental insurance contract has been embraced only by some member states' legislations and its structure is significantly different in each case.

It is also impossible to overlook the part of the obligatory insurance debate in the literature devoted to comparative assessment of two products: first party and third party insurance. Despite the numerous strengths of the former (especially in terms of risk assessment and speed of loss adjustment) the attempt to reinforce the obligation for environmental insurance in the first party system did not gain much publicity in the whole of the EU (Faure, 2001, pp. 16, 59), and the directive clearly points to the necessity to make insurance system subordinate to the rule 'polluter pays' and the polluter's legal liability.

European literature on the subject of obligatoriness in environmental insurance has been recently supplemented by compilations referring to the Chi-

${ }^{3}$ In the recent years, unprecedented obligatory property insurance against the consequences of natural disasters has been introduced in Romania. The reasons for the move referred to alleviation of poverty and social disparities. Researchers have analyzed the issue of poverty and natural disasters in particular regions. According to their findings, the regions with highest poverty rates are the least endangered in terms of natural disasters. As a result, the insurance obligation adds to the people's financial burden, thus making them even poorer. Simultaneously, the likelihood of benefiting from insurance cover is really low. 
nese market where an obligatory environmental insurance pilot program has been running since 2007. On the one hand, scientific analyses show superiority of the obligatory insurance over the non-obligatory one (Feng et al., 2014, p. 217), but on the other hand a number of obstacles to development of this market have been identified. The researchers conclude that establishment of the obligatory system is not a sufficient factor to facilitate market development. They also recommend that action should be taken to increase insurance awareness, support information exchange on the state of the environment, show ways in which environmental regulations might be designed or strengthen preventive systems (Guo, 2016, p. 30). A willingness to participate in creating the conditions for development of insurance market in China has been voiced by the Chinese authorities (Ministry of Ecology and Environment the People's Republic of China, 2016).

\section{Methods}

There are two research purposes of this article. Firstly, to identify the attributes of the EU countries which have implemented a system of obligatory environmental insurance. Secondly, to recognise and assess the premises for introduction of a system of obligatory environmental insurance by the example of Poland. The first of the purposes will be realised on the basis of the analysis of the correlation between the implementation of an obligatory system along with its attributes and the profiles of insurance markets of particular states (gross premium written, insurance density and insurance penetration) and such economic indicators as GDP and GDP per capita. The data for the analysis will be obtained from member states' reports presented to the European Commission (2016b) in 2013 on the basis of art. 18(1) of ELD, statistical data bases of Insurance Europe $(2013 ; 2014 ; 2015)$ and Eurostat $(2016)$.

A narrative analysis of the member states' reports was conducted and the researcher analysed data in their originally written form. This technique ensures that the data is organized with regard to the social or organizational contexts of the research participant.

By reaching the first objective it was possible to identify the economic and insurance market premises for implementation of the obligatory environmental insurance systems. These were collated with the determinants of introduction of obligatory insurance, identified on the basis of literature review and the legal and economic factors of the Polish insurance market. Analysis of the literature resulted in identification of Polish peculiarities of the obligatory insurance. Other research activities like description and drawing logical conclusions from inference were also conducted. 


\section{Results}

\subsection{Obligatory environmental insurance - global perspective}

The report on the evaluation of the environmental directive conducted in 2016 (European Commission 2016a, p. 10) states that approx. one third of the EU member states has implemented a system of obligatory environmental insurance with reference to the scope of liability defined in the directive ${ }^{4}$. The list comprises the following states: Bulgaria, Portugal, Spain, Greece, Hungary, The Czech Republic, Romania and Lithuania. The remaining countries rely on voluntary financial instruments included in the system, primarily focussing on insurance, followed by bank guarantees, special purpose assets or bonds (European Commission 2016a, p. 48). The decision to implement the obligatory system in some cases was not only a prompt response to the directive's requirements ${ }^{5}$ and the decision-making process remained unaccomplished until recently (Hungary, Romania, Lithuania) (European Commission, 2016a, p. 48). This means that for a decade obligatory insurance has been considered to be beneficial, in compliance with the fulfilment of environmental directive principles, i.e. prevention and prudence fostered by the 'polluter pays' rule.

Historically, insurance obligation on the environmental insurance market can be traced back to the international insurance regulations referring to nuclear damage and oil pollution. In the former case, the obligation to insure or otherwise secure financially the liability for a nuclear damage (included environmental damage) is imposed on the entity exploiting the nuclear facility according to the article 7 of the Vienna Convention (International Atomic Energy Agency, 1963). The Vienna Convention is part of the system of liability for nuclear damage set up by the International Atomic Energy Agency (IAEA). An alternative to the IAEA system is the one created by OECD and based on the Paris Convention (OECD, 1960, as amended). Article 10 of the Paris Convention includes obligatory insurance for nuclear installation operators. In the field of oil pollution there have been two liability systems: convention-related (Intergovernmental Maritime Consultative Organization (1969) amended by International Maritime Organization (1992a); Inter-Governmental Maritime Consultative Organization (1971) amended by International Maritime Organization (1992b))

${ }^{4}$ Environmental liability is multidimensional. It covers civil, administrative and criminal liabilities. Insurers' ancillary liability may include the first two of the mentioned above. Solutions accepted by member states differ between one another. The subject of the cited report, however, is primarily the insurance against environmental damage liability from a directive-related point of view (in water, ground, and natural habitats, based on fault or risk, depending on the attributes of the author's activity), and not personal or property-relates damage liability (unless the property is one of the elements of the environment).

5 The date of transposition was set on 30th April 2007, and full transposition was conducted by all member states in mid-2010 (European Commission, 2016b, p. 2). 
and American (Oil Pollution Act, 1990). They both entail obligatory financial security (appropriately certified) to cover the ship's liability and its possible quantitative limitation. Nevertheless, the scope of the claimed damages varies depending on the system (Pepłowska-Dąbrowska, 2011, pp. 121-124).

It should be stated that the obligatory financial security was also considered in the case of other sources of environmental damage. Although the Lugano convention (Council of Europe, 1993) did not introduce unified obligatory financial security measures, it nonetheless - in article 12 - urged the parties to the convention to ensure - where necessary - the entities' participation in the guarantee systems or their purchasing appropriate financial protective instruments (Hinteregger, 2008, p. 4). On the other hand, legal activity of European institutions led to forging a directive proposal referring to the liability for damage caused by waste management (European Commission, 1989; 1993), which introduced risk-based liability, requirement to obtain financial security instruments and the actio directa rule (Coulson \& Dixon, 1995, p. 23). Even though this directive never took effect, it did spark legislative interest in the subject of environmental damage. In 1992 the Green Paper was published with reference to environmental damage liability, and subsequently the White Paper on environmental liability (European Commission, 2000), which became the basis for the environmental directive (Directive 2004/35/CE, 2004) still in force today.

It is worth adding that the issue of obligatory financial security concerning environmental perils is not merely confined to the North-American or European economic area. For instance, we should mention a spectacular proposal of the Chinese Ministry of Environmental Protection of 2015 which urges companies to purchase obligatory insurance against liability for environmental damage resulting from pollution. Similar action has been taken in Argentina, Kazakhstan, the Philippines, Turkey or Turkmenistan (Combeau, 2013).

One should also consider the variety of dimensions referring to the obligation to insure against liability for environmental damage, which may be understood as compulsory within the legal scope of a given country's regulations ${ }^{6}$, but it may also be a form of obligation which is not addressed by the act on compulsory insurance. Hence, the aforementioned lists of states which have established regulations for obligatory environmental insurance may not be complete. This seems to be corroborated by the fact that even though Poland imposes an

${ }^{6}$ In Poland, obligatory insurance has been defined in the article 4 of the Act linked with the article 11 of the Act on compulsory insurance, Insurance Guarantee Fund and Polish Motor Insurers Bureau (2003). According to this act, the only obligatory insurance in Poland is the automobile liability insurance, farmers' liability insurance with reference to farm ownership, insurance of farm buildings against fire and other random events as well as other types of insurance resulting from the regulations of other acts or international agreements ratified by the Republic of Poland which impose on certain entities the obligation to sign an insurance contract. The latter, though, can only be a civil liability insurance. Not all the instances of obligatory insurance in Poland ( 215 has been listed) meet the criteria of obligatoriness imposed by the act (Kowalewski \& Ziemiak, 2015, p. 5). 
insurance obligation, it is listed among the countries pursuing voluntary insurance system. The article 187 of the Act on environmental protection law (2001), contains the possibility of imposition of an obligation by the environment protection authority to ensure the settlement of claims which can potentially result from environmental damage at the moment of issuing the permission to use the environment (an integrated one, a permission for gas or liquid emissions into the air, water licenses for sewage disposal into water or soil or a permission for generating waste) (Maśniak, 2014, p. 150). The UK is a remarkable example, as it feverishly opposes the introduction of obligatory insurance into the system, but at the same time imposes a coercive form in environmental permits. The English and Welsh environmental law enforces examination of the technical competencies of the installation operator in the course of issuing environmental permits. The process of assessment also includes checking the financial security of the permit subject in terms of liability for environmental damage which refers directly to the contents of the permit (European Commission, 2016a, p. 93).

The above observations lead to a conclusion that it is not the obligatoriness as such (or coercion, if we assume synonymous character of both terms), that is perceived as contentious and stimulates dispute over the premises of implementation of the obligatory system. What causes controversies and raises doubts is how this duty should be organised as well as the extent (subjective and objective) to which it limits the freedom of trade on the market of financial services.

\subsection{The concept of harmonisation at the European level}

The regular reviews of the environmental directive with regard to implementation of art. 14 in the member states are an attempt to answer the question whether it is possible and necessary to introduce an obligatory system of insurance against the liability referred to in the directive. The first report of 2010 manifested the restrained attitude of the European Commission. It was asserted that it was too early to evaluate the grounds for application of the obligation and to recommend this solution in the whole of the EU (European Commission, 2010 , p. 8 ) because in some member states obligatory insurance systems were still immature and in some of the others there were difficulties in their implementation. The consecutive report of the European Commission (2016b) had a much broader dimension than merely the analysis of the financial security condition of the liabilities resulting from the directive. The Commission evaluated the effectiveness and efficiency of the directive regulations on the basis of its article 18(2), assessing the environmental insurance market only in this context. It was found that most national markets provide sufficient security with reference to all kinds of risk embraced in the environmental directive. At the same time, an invariably low demand for this kind of products was noticed, especially on the insurance markets which the report refers to as emerging ones (European Commission, 2016b, p. 7). While the report itself disregards the issue of insurance obligatoriness, it points at the importance, from the point of view 
of insurability, of the challenges which the member states face. It recommends standardisation in interpretation of the directive regulations, establishment of data bases and enhancement of risk management systems, because all of these have a positive influence on development of financial security systems (European Commission, 2016b, p. 11). However, one cannot overlook the fact that although the report itself does not touch on the issue of insurance obligatoriness, the working documents of the European Commission on the basis of which the report was compiled reveal the Commission's position on the subject. Pointing at the continuous growth of the voluntary financial instrument market along with far-reaching regulatory disparities between member states ${ }^{7}$ the working document stresses the lack in arguments for creation of a compulsory insurance system harmonised at the EU level. The Commission argues for this standpoint considering the opposition against this system from business entities (potential polluters and insurers alike) (European Commission, 2016a, p. 48).

\subsection{Attributes of member states with a compulsory system ${ }^{8}$}

Insurance obligation has been legitimised in relatively poorly developed countries of the European Union. Economic indicators (GDP, GDP per capita) in majority of the above are usually below the EU average. Also, the attributes of insurance markets (non-life insurance gross premium written, (nonlife) insurance density and insurance penetration rates) in these countries are the evidence of a large discrepancy between them and the highly developed markets. Almost all of them present a rather low level of gross premium written as well as insufficient density and penetration rates. In member states with highly developed insurance markets the principle of contractual voluntariness prevails in the area of insurance. Obligation - if it exists - is not absolute. It only constitutes a tool in the hands of public administration authorities. Spain is an exception to these relations, as it has introduced obligatory environmental insurance, and in such terms as GDP or gross premium written it is ranked well above the EU average. Also, Spain and The Czech Republic show a high penetration rate. This means that the part of GDP they allocate to insurance is similar to the amount secured by the countries which have largely based their environmental risk management on voluntary insurance. A rather high pen-

7 A unified system of obligatory insurance may be hindered by a regulatory barrier in the form of definition of obligatory insurance (not necessarily in all the cases of obligation). For example, in Germany, confining obligatory insurance only to third party liability products makes it impossible to implement obligatory property insurance against catastrophe risk (Insurance Europe, 2013, p. 4). The regime of obligatory insurance in Poland is even more restrictive and encompasses only — with just a single exception - civil liability insurance, while the insurance covering potential liability resulting from the environmental directive also include administrative liability and not the civil one (Krajewski, 2016; Lemkowska, 2013, pp. 57-70).

8 The data for analysis has been obtained from the reports of member states submitted to the European Commission (2016b) in 2013 on the basis of article 18(1) of ELD. 
etration rate is a proof of quite high level of insurance awareness, especially in medium-developed states (measured in GDP per capita) ${ }^{9}$. The systems of obligatory environmental insurance in Spain and the Czech Republic are the most mature ones among the states which have implemented insurance obligation. The obligation is one of the numerous elements of environmental risk management. It is not imposed ex lege on all the entities operating in the areas defined by regulations, but it depends on the outcomes of the risk assessment processes (the scope of the potential damage). Both countries have established thresholds for the potential scope of damage, the violation of which causes insurance obligation to arise. Spain has additionally related the threshold level to the potential polluter's implementation of eco-management system and EMAS audit or the ISO 14001 environmental management system. Hence, Spain has assumed that within a certain scope of risk management, environmental management systems and economic insurance are substitutional towards each other. It is important to emphasise that Spain has supported the entities which use the environment ever since the introduction of obligatory insurance. The regulative preparation of systems for environmental risk management is of special importance to small and medium enterprises which present similar risk profiles and whose management systems are easily standardised. Legal principles of environmental risk management have also been established in Slovakia. However, the environmental attributes of a given organisation's system in Slovakia do not determine the insurance obligation. They only affect the required amount of insurance.

In the other five states insurance obligation is not so strongly supported with the operations within the broadly understood environmental risk management. Most countries declare taking informative action such as circulating brochures, organising workshops, but they do not provide any particular management instruments. Imposition of the obligation seems to become merely a scripted response to the directive call, without creating the conditions which would be conducive to development of the environmental insurance market.

In most cases the obligation has already been proposed in the act aimed at implementation of the directives' assertions into the local legal system. Very often, though, a longer waiting period for regulations concerning obligation was suggested. As a result, the obligatory system did not become operational until a few years after the transposition of directives in the member states. Particularly long waiting periods have been assumed in the aforementioned states, i.e. Spain, The Czech Republic and Slovakia, where the structure of this obligation required the principles of environmental risk management systems to be pre-

9 In the highest-ranking countries in terms of the GDP per capita a high penetration rate is largely generated by income-related factors: willingness to buy insurance, as luxury asset, grows along with the increase in the income. In countries with low or medium level of GDP per capita a high penetration rate may be explained with institutional factors, including level of insurance awareness. See i.e. Bednarczyk (2011, p. 97) and Rozumek (2013, p. 254). 
pared first. In some countries, the decision to impose obligation to be insured against liabilities mentioned in the directive seems to originate from their past experiences. Romania and Hungary in fact provided for insurance obligation with certain types of environmental risk as early as in the nineties of the 20th century, so it was only natural to respond to the directive's call with an extension of the existing obligations. At the same time, it is worth mentioning that only Hungary (in certain regulatory areas) limits the obligatory financial security to insurance. All the remaining states allow for other financial instruments.

The introduction of obligatory financial provision is not correlated strongly with the number of events (a threat of damage or occurrence of damage) imposed by the directive. No correspondence has been noticed either, between extreme occurrences (worth more than 1 mln EUR, both the ones which happened before and after the day of implementation of the directive into the local legal systems) and the existence of obligatory insurance.

Poland is relatively high considering absolute overall economic measures and insurance market indicators in the ranking list of all European Union states. Relatively measures of Polish economy as the whole and Polish insurance market are however weak and put this country (in economic terms) in the group of states which have decided to introduce obligatory environmental insurance.

\subsection{Determinants of implementation of obligatory insurance - theoretical analysis}

Since the issue of the environmental directive ten years ago and in the light of the existing reports from the European Commission it can be clearly seen that a common European system of obligatory insurance will not be introduced in the near future. It does not mean, though, that there is no need for discussion on the necessity to implement such systems in particular countries. In Poland coercion is not tantamount to implementation of the obligation in the sense of the Act on compulsory insurance. It may constitute an extension of the aforementioned article 187 of the Law on environmental protection and be presented as a requirement parallel to an administrative decision (e.g. a decision concerning environmental conditions). An insurance receipt may also become an obligatory document and a precondition for effectiveness of the process of obligatory company registration. Establishment of a system of financial security at the country level results in already mentioned flexibility in its adaptation to legal regulations and administrative or economic processes currently in force.

\subsubsection{Socially significant value}

There is no doubt from the doctrinal point of view that within market economy insurance obligation should be an exception, not a rule (Kamiński, 2014, p. 47). The Polish experience of 'inflation of obligatoriness' is perceived as by all means negative phenomenon (Kowalewski, 2013, p. 5). Administratively 
imposed insurance obligation should be merely confined to securing 'socially significant values' (Orlicki, 2011, p. 95). It seems preposterous to question the significance of the natural environment as a particularly important value in the times of prevalence of the sustainable development paradigm. It was several decades ago that mankind realised that economic growth is only beneficial if it is socially responsible and is achieved with respect for the natural environment. One can see this primarily at the legislative level of various states and various forms of their international associations. Nevertheless, executive power of the sustainable development paradigm is usually contingent upon the current economic situation. The difference in maturity of environmental insurance markets in developed member states and emerging economies seems to prove this point (European Commission, 2016b, p. 7). A significant value, if recognised and properly protected, does not require excessive government interventionism. On the other hand, a value which is considered significant within the political vision of the state but it is not properly protected against the free market operations because of the economic situation is a sound argument for implementation of obligatory insurance. Feeble development of environmental insurance in Poland, a limited offer from insurers along with low level of awareness concerning environmental insurance products is good enough evidence for the necessity of debate on the introduction of obligatory insurance in the researched subject area.

Sustainable development, in very general terms, is about the necessity to consider the external impact of economic activity. It was exactly the same goal that the European legislator had in mind when issuing the environmental directive: to commit the author of the environmental damage to prevent and remedy it (if the preventive measures prove insufficient) and to bear the costs of the action taken (thus relieving the taxpayers from incurring them). This, in turn, means that the external impact of the economic activity should be internalised (European Commission, 2016a, p. 10). At the same time, it is worth noting that imposition of liability without establishing suitable financial security instruments frequently proves fruitless (European Commission, 2016b, p. 19), even if according to prof. Wilczyński's proposal, in the market economy 'liberalisation happens parallel to tough economic terms'. That is to say, the freedom of decision-making with regard to insurance is linked with the principle of absolute liability for business operations (Handschke, 1998, p. 69). However, application of such economic coercion in the above shape will not necessarily lead to appropriate level of internalisation of the external impact. Such factors as the cost of remedying environmental damage, time factor, which is key, as well as the absolute necessity to remedy the environmental damage juxtaposed with the authors' financial potential often result in a direct financial engagement of public administration. 


\subsubsection{The scale of environmental damage vs. capacity of insurance sector}

Analysis of environmental damage cases remedied on the basis of the ELD since it came into effect has shown that the damages which underwent remedying action were worth $6 \mathrm{mln}$ EUR excluding the five greatest disasters and $180 \mathrm{mln}$ EUR in total, including these five. On the average, the costs of remedying action amounted to approx. 42,0 EUR ${ }^{10}$. In individual cases the amounts varied from several thousand Euros to over 50 mln EUR (Kolontár, Moerdijk), (European Commission, 2016b, p. 6). Without proper security, they could lead to author's insolvency (Hawser, 2012) and consequently result in covering the costs of remedying from the public funds. Therefore, it is essential to consider the necessity of obligatory insurance, especially with reference to the entities whose activity may lead to significant financial burdens for public finance in the event of materialisation of environmental risk.

Insurance sector continuously declares its growing capacity for environmental risk, although it is still lower than in the remaining areas of the sector (transport or legal liability) (Insurance Europe, 2013, p. 14) In 2014 most insurers offered an environmental risk cover amounting to 1-5 mln EUR. In some cases, insurers declare a cover up to 50 mln EUR or even more if this is the expectation of the demand side. The crucial market determinant is however the lack of sufficient interest of the demand side (Insurance Europe, 2014, p. $5)$. In turn, demand originates from insurance awareness and economic capabilities of the subject of risk (price - financial capacity ratio). It is obligatory insurance that can indeed be one of the methods of improvement of the above factors. Insurance obligation on the one hand eliminates the issue of insufficient insurance awareness, and on the other hand has a direct positive impact on meeting the technical criteria for running insurance operations (the law of large numbers, the principle of insurance portfolio homogeneity, risk diversification) and an indirect impact on the insurance product price. Summing up, on the markets where the demand-reducing factors determine the environmental insurance market, introduction of obligatory insurance may be indispensable, at least in the short term.

The assumption of the short-term perspective of insurance obligation and at the same time the attempt to accomplish the aforementioned positive consequences of the obligation requires parallel action aimed at developing awareness or even changing the culture of environmental risk management. The quasi-regulatory role of insurers becomes especially relevant in this situation, as they are the decision-makers in the underwriting process and in accepting (or not) a risk to be insured. In the obligatory insurance system, insurers by imposing requirements on the potential insureds with respect to environmental risk management and by adapting the premium as well as the terms of insur-

10 With the exception of the three unusual cases (Kolontár - Hungary; Moerdijk Netherlands; Assopos — Greece) — extreme values. 
ance to the scope of the risk taken, may contribute to developing correct attitudes to the natural environment (eo ipso their actions will lead to fulfilment of the superior goal of the environmental directive, i.e. damage prevention in the natural environment). For the above to be accomplished, two preconditions must be met. Firstly, the obligation to sign an insurance contract must be one-sided, imposed only on the insured. At the same time, the insurer should be given the right to decide whether to accept the risk or to reject it due to its unacceptable attributes. This solution, while it is contrary to the Polish law at the moment ${ }^{11}$, forces the protection seeker to physically control environmental risk. It is only adequate when supply of the insurance protection is sufficiently big, which means the insurance market is well developed. Nowadays, this condition is not fulfilled on the Polish market. Only three insurance companies offer specialised environmental insurance in Poland. Therefore, introduction of obligatory insurance cannot be only a one-off action deprived of a broader context, aimed at strengthening environmental risk cover. It should be the element of a broadly planned insurance - environmental policy followed by such actions as e.g. execution of legal penalties for environment violation, transparent rules of granting permissions to use the environment or, finally, establishing data bases referring to materialisation of environmental risk, costs of preventive and remedying actions.

The other condition for effectiveness of quasi-regulatory insurers' activity is the quality of the underwriting process in the scale of the whole market. Paradoxically, a highly competitive market acts against effectiveness with reference to fulfilment of the environmental directive aims (tough competition results in growing price rivalry and neglecting the rules of underwriting in the booming market). On the other hand, attributes of environmental risk (its relatively low insurability) are conducive to occurrence of the above behaviours (a limited number of providers, risk perceived as difficult and laying a great burden on the insurer's capital).

\subsubsection{The market's capacity for self-development}

Those who oppose the introduction of obligatory environmental insurance quote the examples of markets with a high penetration rate. The first market to be mentioned is usually the German one, where flexible solutions brought a desirable effect and insurance awareness grew without the imposition of obligatory insurance. The European insurers' association is absolutely and consistently opposing introduction of a European obligatory system, asserting that

${ }^{11}$ Cf. article 5 par. 2 of the Act on compulsory insurance, Insurance Guarantee Fund and Polish Motor Insurers Bureau (2003). More on the legal aspects of obligatory contracts (Krajewski, 2014, pp. 34-45). Individual solutions, similar to the above, in the legislations of European states contain arguments against a unified system of environmental insurance in the EU. A possible obligation - if it should prove necessary in a member state, must be tailored to fit in the local legal system. 
wherever possible, voluntary market should be strengthened. Each time obligatory insurance is introduced there is a threat that the market may become sluggish, products will lose their flexibility, supply will be lower and the entities burdened with the obligation (potential authors of environmental damage) will face the problem of having no product range adapted to their individual needs (Insurance Europe, 2013, p. 13; 2014, p. 2; 2015, p. 36). The European Commission reports show a systematic increase in the voluntary insurance market. It must be stated, though, that this growth is not happening on its own. It is stimulated by various forms of fulfilment of the environmental directive's postulate presented in paragraph 14 (instructions for technical and economic assessment of the condition of the environment, instructions and procedures for risk assessment etc.). The example of German market quoted above emphasises active participation in its development of the German association of insurers (Gesamtverband der Deutschen Versicherungswirtschaft), which has prepared model general conditions of environmental insurance to facilitate signing contracts for these products. Nevertheless, as it has already been said, obligatory solutions should not be treated as alternative to other initiatives fostering market growth. If the obligation were considered necessary, it should be merely one of many elements of a broadly planned environmental risk management system at the state level.

\subsubsection{Problems of obligatory insurance systems}

By way of conclusion and complementation of the above reflections one should also identify the set of difficulties potentially generated by insurance obligation. This in turn constitutes an organisational problem of its own as an obligatory system may be formed in a variety of ways, while its attributes can either strengthen or eliminate some of the problems. Due to this, the identified factors have been grouped according to a subject criterion into three categories, with reference to particular groups of stakeholders of the environmental insurance market (insurers, insureds, state). Subsequently, for each factor a structural solution has been suggested to possibly eliminate or reduce its adverse influence.

Obligatory insurance systems may violate insurers' interest in two areas. Firstly, in terms of limitation of insurers' freedom to enter into a contract. Secondly, in terms of lack of voluntariness in the structure of the terms and conditions of the contract. Violations in both areas contradict the essential technical rules of running insurance operations. Risk assessment should become the basis for the insurer to decide about acceptance of the risk as insurable, to calculate the premium at the level which will make it possible to cover the future liabilities within a given product line. Moreover, the scope of the protection should be derived from the capital capacity of the insurer, and not the effect of the imposed conditions. Furthermore, particular contractual regulations should be correlated with individual risk attributes (e.g. technical-insurance constraints and their scope adapted to the degree of implementation of physical check in- 
struments referring to the potential insured's risk). Due to insurers' sceptical attitude to covering environmental risk (because of its subjective 'uninsurability' in most cases) all the rigid regulations of the protection scope and an obligation for insurers to sign contracts ${ }^{12}$ may in fact result in insurers' withdrawal, limitation of the supply of insurance products and finally, shrinking of the market.

The negative impact of the system mentioned above may be mitigated if the obligation is established only for the purchaser of the product, and the insurers may shape the conditions on their own on the basis of their know-how of insurance industry. Additionally, it must be said that another barrier to development of environmental insurance market is the relative weakness of the very same know-how and limited access to qualified experts in the field of environmental risk assessment or environmental damage settlement. The obligatory system does not support the insurance sector against such shortcomings.

An overly restrictive compulsory system which excessively limits insurers' freedom leads to shrinking supply of protection regarding environmental risk will inevitably force potential buyers (insureds) to seek the product of which there is no sufficient supply on the domestic market. Creating artificial, obligatory demand in the conditions of an emerging market of environmental insurance with a small number of entities offering protection may lead to a rise in monopolistic practices. Growing prices will additionally burden the insureds, at the same time limiting product accessibility for the entities which are not liable to this obligation. Moreover, development of the obligatory system results in a top-down compilation of a set of potential insureds. Surely, on the one hand creating a collection of insureds is indispensable for non-life insurance to exist, but on the other hand it generates a tendency for negative selection (usually, entities which present higher than average risk are primarily liable to obligatory insurance) which in turn has an adverse effect on the price of insurance cover.

It seems that the potential structure of obligatory insurance system shows little flexibility in dealing with problems of insureds. Obviously, it is possible to increase the number of entities which would be liable to the obligation, (thus diminishing the phenomenon of negative selection). However, first of all, it is absolutely crucial to offer - parallel to the obligatory system - additional incentives for development of the supply side (increasing prevention of causing environmental risk through a system of penalties, creating data bases, instructions, guidelines for environmental risk management systems, which lead to greater market transparency and make it easier to provide cover). The major condition for an obligatory system to function well is therefore ensuring a sufficiently mature supply side of the market.

The European Parliament has pointed out that in the end it is the state or local authorities that bear the direct or indirect cost resulting from environmental disasters - both natural and man-inflicted (including the ones which generate environmental damage). A badly designed system will not only fail to relieve public finance but it may also limit the positive aspects of economic develop-

\footnotetext{
${ }^{12}$ Like the one in Poland, described above.
} 
ment. The above scenario may become true if the conditions for providing insurance cover are restrictive to an extent which will force the insurers to withdraw from the market. Lack of supply of insurance products or their exorbitant pricing will create a barrier for taking up business activity in certain areas. Lack of preventive measures and the phenomenon of moral hazard will lead to losses which exceed the scope of insurers' capacity. Excessive prices and a narrow scope of protection will cause reduction in financial security of the entities which are not liable to the obligation.

\section{Conclusion}

Overall economic indicators for Poland and the attributes of the Polish insurance market put this country (in economic terms) in the group of states which have decided to introduce obligatory environmental insurance. Simultaneously, the doctrine and practitioners alike consistently criticise 'inflation of obligatoriness' which has been seen in the Polish regulations for decades. Moreover, insurance which covers liabilities referring to the environmental damage directive - in the light of the Polish law - would not meet the criteria of obligatory insurance (they do not belong in civil liability cover). However, practice shows that there are no obstacles to introduction of obligation which would not be subject to the Act on compulsory insurance. The advantage of the latter option is the legal possibility of solutions with legally guaranteed flexibility, which, if properly designed, should have no adverse impact on the existing supply on the market. Nonetheless, a crucial barrier to introduction of insurance obligation in Poland is the shortage of supply. The low number of insurance companies, that offer specialized environmental insurance lead to an increase in monopolistic practices in obligatory insurance (particularly, an increase in prices while offering a limited scope of insurance). This, in turn, may weaken the development potential of the industries which are obliged to have the insurance coverage on the one hand and on the other - reduce financial security of the entities which are not liable to the obligation.

Possible introduction of insurance obligation should be preceded by action taken in order to strengthen the supply side of the market i.e. developing data bases on environmental risk, fostering systems (useful from the point of view of insurers) of environmental management in potential polluters' organisations, compiling model general conditions, preparing transparent administrative procedures for environmental damage remedying and interpretations of legal regulations with regard to damage remedying. Thorough information about risk and well-developed physical checks should increase the insurers' willingness to expand this product line. Only in these conditions will it be possible for obligatory insurance - flexible enough in its structure - to strengthen the incentives for market development on the demand side. 


\section{References}

Ad-hoc Industry Natural Resource Management Group. (2009). White paper: financial security and insurance aspects of the European Union environmental liability directive. Retrieved 30.05.2018 from http://nrdonline.org.

Bednarczyk, T.H. (2011). Ekonomiczne i instytucjonalne czynniki rozwoju ubezpieczeń. Wiadomości ubezpieczeniowe, 4.

Bergkamp, L., \& Goldsmith B. (2013). The environmental liability directive: a commentary. Oxford: Oxford University Press.

Bou-Habib, P. (2006). Compulsory insurance without paternalism. Utilitas, 18(03). doi:10.1017/S0953820806002020.

Combeau, J. (2013). Can mandatory environmental insurance resolve pollution problems in China? Retrieved 28.10.2016 from http://ww2.cfo.com.

Coulson, A.B., \& Dixon, R. (1995). Environmental risk and management strategy: the implications for financial institutions. International Journal of Bank Marketing, 13(2). doi:10.1108/02652329510078668.

Council of Europe. (1993). Convention on civil liability for damage resulting from activities dangerous to the environment. CETS no. 150.

Directive 2004/35/CE of the European Parliament and of the Council of 21 April 2004 on environmental liability with regard to the prevention and remedying of environmental damage (OJ L 143, 30.4.2004).

Dragota, I.M., Semenescu, A., \& Gherasim, A. (2012). Compulsory insurance for dwellings in Romania between mitigating the impacts of natural disasters and giving rise to social inequities. African Journal of Business Management, 6(1). doi:10.5897/ajbmll.1711.

European Commission. (1989). Proposal for a Council Directive on civil liability for damage caused by waste. COM(89)282 (OJ C 251, 4.10.1989).

European Commission. (1993). Amended proposal for a Council Directive on the landfill of waste. COM(93)275 (OJ C 212, 5.8.1993).

European Commission. (2000). White paper on environmental liability. $\operatorname{COM}(2000) 66$.

European Commission. (2010). Report from the Commission to the Council, the European Parliament, The European Economic and Social Committee and The Committee of the Regions, under article 14(2) of Directive 2004/35/CE on the environmental liability with regard to the prevention and remedying of environmental damage. COM(2010)581.

European Commission. (2016a). REFIT evaluation of the environmental liability directive. $\operatorname{SWD}(2016) 121$.

European Commission. (2016b). Report from the Commission to the Council and the European Parliament under Article 18(2) of Directive 2004/35/EC on environmental liability with regard to the prevention and remedying of environmental damage. $\operatorname{COM}(2016) 204$.

Eurostat. (2016). Retrieved 31.10.2016 from http://ec.europa.eu/eurostat. 
Faure, M. (2001). Environmental damage insurance in theory and practice. Paper presented at The law and economics of environmental policy: a symposium, London.

Faure, M.G. (2006). Economic criteria for compulsory insurance. The Geneva Papers on Risk and Insurance - Issues and Practice, 31(1). doi:10.1057/palgrave.gpp.2510063.

Feng, Y., Mol, A.P.J., Lu, Y., He, G., \& van Koppen, C.S.A. (2014). Environmental pollution liability insurance in China: compulsory or voluntary? Journal of Cleaner Production, 70. doi:10.1016/j.jclepro.2014.02.027.

Franc, C., \& Pierre, A. (2015). Compulsory private complementary health insurance offered by employers in Franca: implications and current debate. Health Policy, 119(2). doi:10.1016/j.healthpol.2014.12.014.

Gauci, G. (2014). Compulsory Insurance Under EC Directive 2009/20/EC: an adequate solution for victims, or is it also time for the abolition of maritime limitation of liability and the establishment of an international fund as an insurer of last resort. Journal of Maritime Law and Commerce, 45(1).

Guo, H. (2016). Research on the way of promoting environmental pollution liability insurance in China. International Journal of Business Administration, 7(1). doi:10.5430/ijba.v7nlp26.

Handschke, J. (1998). Pojęcie, treść i zasady polityki ubezpieczeniowej — rozważania nie tylko metodologiczne. In T. Sangowski (Ed.), Studia ubezpieczeniowe. Poznań: Akademia Ekonomiczna w Poznaniu.

Hawser, A. (2012). Environmental risk insurance. Global Finance, January 6.

Hinteregger, M. (2008). International and supranational systems of environmental liability in Europe. In M. Hinteregger (Ed.), Environmental liability and ecological damage in European law. Cambridge: Cambridge University Press. doi:10.1017/CBO9780511494970.004.

Insurance Europe. (2013). Insurance Europe response to the European Commission's green paper on insurance of natural and man-made disasters. Retrieved 10.06.2017 from https://www.insuranceeurope.eu.

Insurance Europe. (2014). Survey of environmental liability insurance developments. Retrieved 10.06.2017 from https://www.insuranceeurope.eu.

Insurance Europe. (2015). Annual report 2014-2015. Retrieved 10.06.2017 from https://www.insuranceeurope.eu.

Intergovernmental Maritime Consultative Organization. (1969). International Convention on civil liability for oil pollution damage. 973 UNTS 3; 9 ILM 45

Inter-Governmental Maritime Consultative Organization. (1971). International Convention on the establishment of an international fund for compensation for oil pollution damage. 1110 UNTS 57.

International Atomic Energy Agency. (1963). Vienna convention on civil liability for nuclear damage of May 21th 1963, amended by Protocol of September 12th 1997. 1155 UNTS 331. 
International Maritime Organization. (1992a). Protocol of 1992 to amend the International convention on civil liability for oil pollution damage of 29 November 1969. 1956 UNTS 255.

International Maritime Organization. (1992b). Protocol of 1992 to amend the International convention on the establishment of an international fund for compensation for oil pollution damage of 18 December 1971. 1953 UNTS 330.

Kamiński, R. (2014). Wpływ ubezpieczeń obowiązkowych na konkurencje ubezpieczycieli oraz sytuację ubezpieczonych. Prawo Asekuracyjne, 3(80).

Kowalewski, E. (Ed.). (2013). Stan prawny ubezpieczeń obowiązkowych w Polsce. Warszawa: Polska Izba Ubezpieczeń.

Kowalewski, E., \& Ziemiak, M.P. (2015). Stan prawny ubezpieczeń obowiązkowych w Polsce. Wstęp. Wiadomości Ubezpieczeniowe, 1.

Krajewski, M. (2014). Obowiązek zawarcia umowy ubezpieczenia po stronie ubezpieczyciela. Prawo Asekuracyjne, 3(80).

Krajewski, M. (2016). Umowa ubezpieczenia art. 805-834 KC. Komentarz. Warszawa: C.H. Beck.

Lemkowska, M. (2013). Ubezpieczenia odpowiedzialności administracyjnej za szkody w środowisku — problemy prawne. Prawo Asekuracyjne, 1(74).

Maśniak, D. (2014). Ubezpieczenia jako instrument zarządzania katastrofami spowodowanymi przez człowieka - perspektywa unijna. Prawo Asekuracyjne, 3(80).

Ministry of Ecology and Environment the People's Republic of China. (2016). Establish green finance policy framework and promote the improvement of environmental quality. Retrieved 27.09.2016 from http://english.sepa.gov.cn.

OECD. (1960). Paris convention on third party liability in the field of nuclear energy of June 29th 1960, amended by Protocol of January 28th 1964 and Protocol of November 16th 1982. 956 UNTS 251.

Oil Pollution Act of 1990 (33 U.S.C. 2701-2761).

Orlicki, M. (2011). Ubezpieczenia obowiązkowe. Warszawa: Wolters Kluwer Polska.

Pepłowska-Dąbrowska, Z. (2011). Konwencyjny system odpowiedzialności za szkody spowodowane zanieczyszczeniem olejami a amerykański Oil Pollution Act. Prawo Morskie, XXVII.

Rozumek, P. (2013). Analiza poziomu rozwoju czeskiego, polskiego, słowackiego i węgierskiego rynku ubezpieczeniowego na podstawie modelu krzywej S. Zarządzanie i Finanse, 11(2).

Ustawa z dnia 22 maja 2003 r. o ubezpieczeniach obowiązkowych, Ubezpieczeniowym Funduszu Gwarancyjnym i Polskim Biurze Ubezpieczycieli Komunikacyjnych [Act of 22 May 2003 on compulsory insurance, Insurance Guarantee Fund and Polish Motor Insurers Bureau] (Dz.U. 2003 nr 124 poz. 1152) (Poland).

Ustawa z dnia 27 kwietnia $2001 \mathrm{r}$. Prawo ochrony środowiska [Act of 27 April 2001 on environmental protection law] (Dz.U. $2001 \mathrm{nr} 62$ poz. 627) (Poland). 
Zhu, L. (2014). Probing compulsory insurance for maritime liability. Journal of Maritime Law \& Commerce, 45(1).

\section{Acknowledgements}

Author contributions: author has given an approval to the final version of the article.

Funding: this research was undertaken as part of the Private insurance and environmental management systems complying with ISO 14001 as tools of environmental risk's management analysis of relations project and was fully funded by the National Science Centre, Poland under the grant (2016/23/D/HS4/02654).

Note: the results of this study were presented at 21st Asia Pacific Risk and Insurance Association Annual Conference Challenges in the Insurance Market: Transparency and Consumer Protection (July, 30-August, 2 2017, Poznań, Poland). 
